\title{
Re-description of Dysponetus joeli Olivier et al., 2012 (Polychaeta, Chrysopetalidae), with a new key to species of the genus
}

\author{
Teresa DARBYSHIRE \\ Department of Biodiversity \& Systematic Biology, Amgueddfa Cymru - National Museum Wales, \\ Cathays Park, Cardiff CF10 3NP, Wales, U.K. \\ Email: Teresa.Darbyshire@museumwales.ac.uk
}

urn:lsid:zoobank.org:author:B7103B9C-2A1A-4ADC-BC28-55EA9B8850C9

\begin{abstract}
Dysponetus is a genus of the family Chrysopetalidae with twelve currently described species. Specimens are fragile and easily damaged or broken during sampling making identification difficult. The most recently described species, Dysponetus joeli Olivier et al., 2012, from the Bay of Biscay and the English Channel, was described from a few small, damaged and poorly preserved specimens. New specimens from the Isles of Scilly, in much better condition, resembled $D$. joeli except for the absence of ventral cirri on segment 3. Examination of the type material of $D$. joeli showed it to be identical to these new specimens and highlighted errors in the original description of the species. The present paper corrects the errors and a revised key to species is produced. The differences between $D$. joeli and the two most similar species, D. bipapillatus Dahlgren, 1996 and D. macroculatus Dahlgren, 1996 are also detailed.
\end{abstract}

Keywords. Dysponetus, tentacular cirri, ventral cirri, cirrophores.

Darbyshire T. 2012. Re-description of Dysponetus joeli Olivier et al., 2012 (Polychaeta, Chrysopetalidae), with a new key to species of the genus. European Journal of Taxonomy 27: 1-9. http://dx.doi.org/10.5852/ejt.2012.27

\section{Introduction}

There are currently twelve described species of the genus Dysponetus Levinsen, 1879 from around the world. Most occur in shallow water and, with a few exceptions, are distributed in the Atlantic region. All are small and fragile and rarely recorded from surveys, most likely because they are easily overlooked or found in fragments not identifiable to species level. Several species are known only from their original description and, even where multiple records do exist, these number in single figures.

Five species have been described for the northeast Atlantic region: D. caecus (Langerhans, 1880), D. gracilis Hartman, 1965, D. paleophorus Hartmann-Schröder, 1974, D. pygmaeus Levinsen, 1879 and D. joeli Olivier et al., 2012. All of these have potential to be found in UK waters although only two currently are. Dysponetus gracilis is, as yet, only recorded from deep water ( $>400 \mathrm{~m})$ samples outside of the UK (Hartman 1965; Hartman \& Fauchald 1971; Aguirrezabalaga et al. 1999), D. paleophorus has not been recorded since its first description off Norway and records for D. pygmaeus are restricted to the Arctic and Japanese Pacific (Levinsen 1879; Annenkova 1935; Imajima \& Hartman 1964). Dysponetus 
caecus, the most recorded Dysponetus species, has been identified from shallow littoral samples from the UK (Scotland: Dahlgren \& Pleijel 1995) as well as from other European locations (Laubier 1964; O' Connor 1981; Kirkegaard 1992; Parapar \& San Martín 1993; Dahlgren \& Pleijel 1995; Brito et al. 1996). An anomalous addition to these records would appear to be the records of Böggemann (2009) from the abyssal southeast Atlantic. However, Böggemann addresses this anomaly in his paper by suggesting that the lack of previous records from this region and depth is related to its small size and fragility (probably the scarcity of previous samples too). Most recently, D. joeli was described from four shallow sites in the UK and France.

In 2009, a National Museum Wales subtidal survey of the Isles of Scilly, an island archipelago off the southwest tip of the UK, collected five specimens of Dysponetus in coarse sandy sediments. Initial examination of the specimens showed them to possess four eyes, a character possessed by half of the Dysponetus species, none of which, at that time, were described for the UK. Other characters, including the absence of ventral cirri on segment 3, were found that differentiated it from all but two other Dysponetus species, D. bipapillatus Dahlgren, 1996 from the Mediterranean and D. macroculatus Dahlgren, 1996 from Papua New Guinea. The description of D. joeli was published shortly before the description was finished and the two species showed such great similarity that the type specimens of the latter were obtained and examined in order to determine whether the differences were indeed real or might be due to the damaged nature of the specimens used. Examination of the holotype of D. joeli revealed that the ventral cirri of segment 3 were in fact entirely absent rather than merely detached and lost, and thus the specimens were indeed the same species. Consequently, this required distinguishing characters between $D$. joeli, D. bipapillatus and D. macroculatus to also be detailed. A full re-description is therefore made to clarify the species characters and differentiate it from the two most similar species.

\section{Materials and Methods}

Specimens of Dysponetus joeli were collected during a subtidal survey of the Isles of Scilly in June 2009. Samples were collected using a $0.1 \mathrm{~m}^{2}$ Van Veen grab from the R.V. Sepia of the Marine Biological Association UK. Sediment was elutriated gently with seawater and the resulting sample sorted live the same day. Animals were relaxed in a 7\% magnesium chloride solution and fixed in $4 \%$ formaldehyde. Final preservation was in $80 \%$ alcohol with $2 \%$ propylene glycol added.

The type specimens of $D$. joeli were collected from shallow maerl beds by Day, Van Veen or SmithMcIntyre grab and sieved through a 0.5 or $1.0 \mathrm{~mm}$ mesh (Olivier et al. 2012).

All drawings and measurements were made using a camera lucida attachment on a Nikon Labophot-2 compound microscope or a Nikon Eclipse E400 binocular microscope. Microscope photographs were taken using AutoMontage ${ }^{\mathrm{TM}}$ software and SEM images were obtained using a Neoscope SEM.

Type specimens of $D$. joeli are held in the collections of the Muséum National d'Histoire Naturelle in Paris (MNHN) and the new specimens from the Isles of Scilly are in the National Museum Wales collections (NMW.Z). Specimens of D. bipapillatus and D. macroculatus were borrowed from the Swedish Museum of Natural History (SMNH) to enable a full comparison of characters.

\section{Results}

Phylum Annelida Lamarck, 1809

Class Polychaeta Grube, 1850

Family Chrysopetalidae Ehlers, 1864

Genus Dysponetus Levinsen, 1879 
Dysponetus joeli Olivier et al., 2012

Figs 1A-D, 2A-D

Dysponetus joeli Olivier et al., 2012: 989-996, figs 1-3.

\section{Material examined}

Chausey, France, Sta. SSMM01 (48 55.570’ N, 001 48.270’ W), maerl, 10.0 m, holotype (MNHN POLY TYPE 1533), paratype (MNHN POLY TYPE 1534), 18 Apr. 2006; off St Mary's, Isles of Scilly, Sta. 3 b (49 $\left.54.20^{\prime} \mathrm{N}, 006^{\circ} 18.94^{\prime} \mathrm{W}\right)$, coarse sand/shell/gravel with some silt/clay, $25 \mathrm{~m}, 2$ specimens (NMW.Z.2009.027.0001-0002), 25 Jun. 2009; west of St Martin's, Isles of Scilly, Sta. 14b (495 57.86' $\mathrm{N}, 006^{\circ} 15.21^{\prime} \mathrm{W}$ ), shell gravel in muddy sand, $35.1 \mathrm{~m}, 2$ specimens (NMW.Z.2009.027.0003-0004), 27 Jun. 2009; west of Isles of Scilly, Sta. $24 \mathrm{~b}\left(49^{\circ} 55.22^{\prime}\right.$ N, $006^{\circ} 23.91^{\prime}$ W), silty coarse sand/shell gravel, 47.1 m, 1 specimen used for SEM (NMW.Z.2009.027.0005), 29 Jun. 2009.
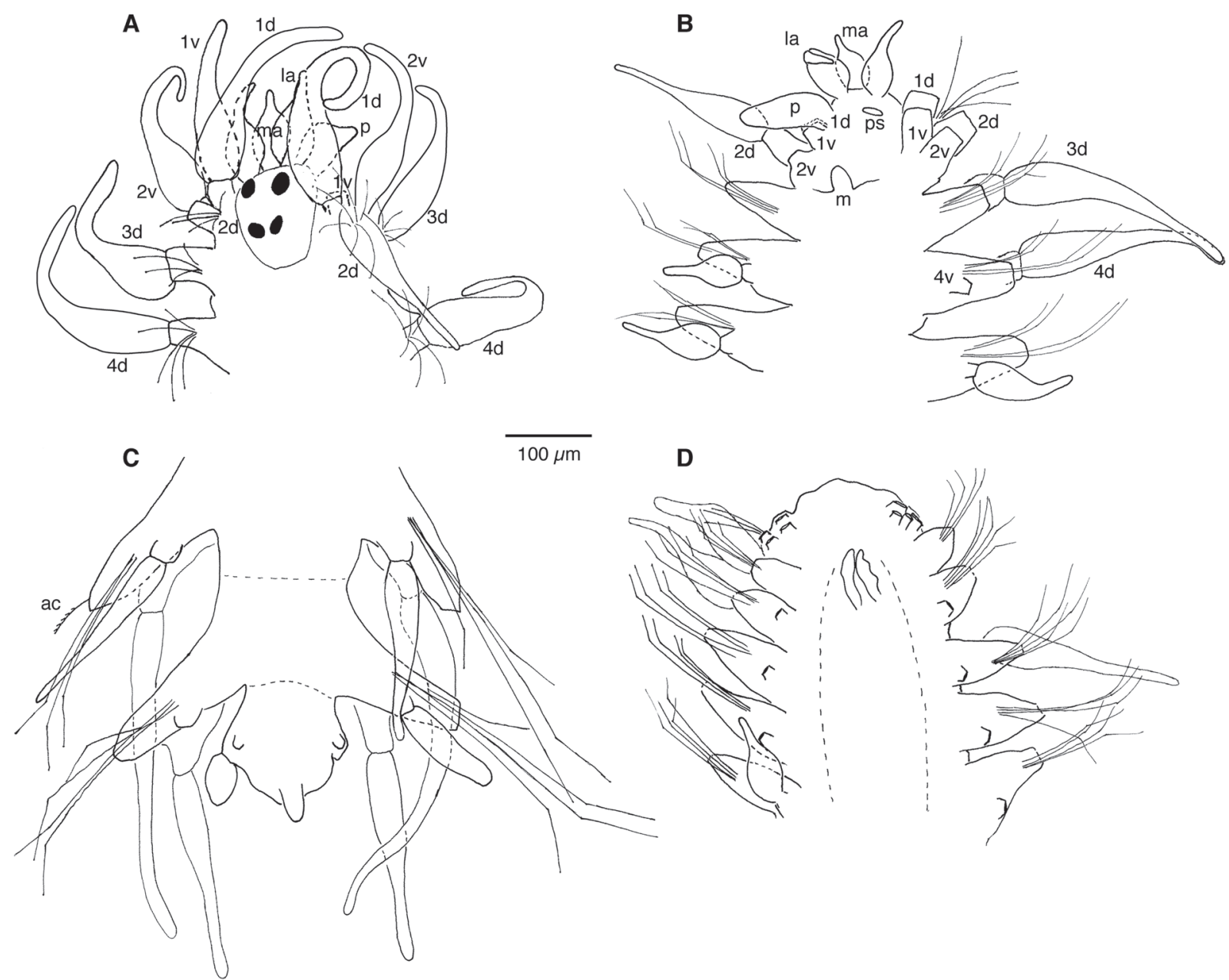

Fig. 1. Dysponetus joeli Olivier et al., 2012. A. NMW.Z.2009.027.0003, anterior end, dorsal view. B. NMW.Z.2009.027.0004, anterior end, ventral view. C. NMW.Z.2009.027.0003, posterior end, ventral view. D. Holotype (MNHN POLY TYPE 1533), anterior end, ventral view. Only a few chaetae drawn in each case for clarity. $-\mathrm{ac}=$ accessory chaeta, $\mathrm{d}=$ dorsal (cirrus/cirrophore), la $=$ lateral antenna, $\mathrm{ma}=$ median antenna, $\mathrm{m}=$ mouth appendage, $\mathrm{p}=$ palp, $\mathrm{ps}=$ palp scar, $\mathrm{v}=$ ventral (cirrus/cirrophore); numbers indicate the segment. 


\section{Description}

Holotype in 4 pieces, posteriorly incomplete, $3.1 \mathrm{~mm}$ long for 19 chaetigers. Paratype in 3 pieces, anterior dissected fragment of 5 chaetigers with 2 further detached chaetigers. 3 non-type specimens up to $6 \mathrm{~mm}$ long, $0.35 \mathrm{~mm}$ wide (between segments, not including parapodia or chaetae) with 25-33 chaetigers. Two other incomplete non-type specimens examined. The following description is based on entire specimens from the Isles of Scilly, except where specified as pertaining to the type material.

Body shape cylindrical, ventrally flattened, tapered slightly at posterior. Body pale cream in colour (fixed, unstained), eyes dark reddish brown (Fig. 2A) but pigment may degrade in alcohol. Eyes of type specimens already barely discernable.

Prostomium oblong, wider anteriorly (Fig. 1A). Four large, rounded eyes visible in fixed specimens, anterior pair larger and more widely separated than posterior. Median antenna small, bottle-shaped, arising anterodorsally from prostomium. Lateral antennae bottle-shaped, slightly smaller than median, arising immediately dorsal to palps. Antennae without distinct ceratophores. Palps directed posteriorly, stout, oval, more than twice as long as wide. No antennae or palps remaining on type specimens examined. Nuchal organs not observed.

Distinct single mouth appendage on lower lip, anteriorly directed, digitiform with blunt tip (Fig. 1B, 2B). Single pair of stylet-shaped jaws, visible through body wall with methyl green staining. Proboscis not observed.

First two segments slightly elevated dorsally with four pairs tentacular cirri, longer than but with same shape as dorsal cirri of third and following segments, anteriorly directed. First segment achaetous, second segment with notochaetae only, situated slightly anterior to dorsal tentacular cirrus. Third segment biramous; dorsal cirri present, ventral cirri absent (Figs 1A, B, D, 2B). Holotype lacking all cirri on anterior three segments, but presence indicated by cirrophores (Fig. 1D). Following segments all biramous with both dorsal and ventral cirri. Single noto- and neuroacicula present in each parapodium.

Notopodial lobes reduced. Dorsal cirri long, slender, longer than chaetae $(210-430 \mu \mathrm{m}$, longest on median chaetigers), cirrophores present. Styles slightly proximally swollen, distally tapering, tips blunt. Notoacicula difficult to detect. Notochaetae inserted dorsal to cirrus, densely packed, directed posteriorly leaving middle part of dorsum exposed. Chaetae D-shaped in cross-section (Fig. 2C) with denticles sharply pointed, in two parallel rows, $15-20$ on each side. Notochaetal count, mid-body segments, up to 26 .

Neuropodia well-developed, conical mounds. Compound neurochaetae, with heterogomph shafts and fine bidentate falcigerous blades (Fig. 2D). Neurochaetal count, mid-body segments, at least 20-26 (chaetae densely packed and difficult to accurately count). Up to two accessory simple chaetae, similar to but smaller than notochaetae, inserted distally and anteriorly on neuropodial lobe (Fig. 1C). Ventral cirri fusiform, shorter than dorsal cirri (length 110-270 $\mu \mathrm{m}$, longest on median chaetigers), arising posteroventrally on neuropodial lobe (Fig. 1C).

Final segment lacking noto- and neurochaetae, cirrophores of dorsal and ventral cirri observed although only a single, rounded dorsal cirrus observed on 1 specimen (NMW.Z.2009.027.0003). Pygidium conical with single projection (length $40 \mu \mathrm{m}$ ), cylindrical, slightly distally tapering, inserted posteroventrally (Fig. 1C), anus terminal.

Eggs visible within one specimen (NMW.Z.2009.027.0001), flattened oval in shape, maximum width approx. $50 \mu \mathrm{m}$, possibly immature. 


\section{Habitat}

The species was originally described from maerl beds in the Bay of Biscay and the English Channel. The new specimens are all from coarse sand and shell sediments collected around the Isles of Scilly.

\section{Remarks}

The original description of $D$. joeli was based on small, damaged specimens and this may explain why the absence of the ventral cirri on chaetiger 3 was attributed to loss of the cirri rather than actual absence. Although cirri are easily lost from specimens, the cirrophores can still be seen under light microscopy at x400 magnification or greater. Application of methyl green staining can help distinguish these features. Under SEM conditions the absence of cirrophores on chaetiger 3 is obvious (Fig. 2B).

An additional complication in determining the described characters of $D$. joeli arises from the character matrix scores in the original paper (Olivier et al. 2012). In their species description, the authors stated that there were 2 pairs of tentacular cirri on the first 2 segments but made no mention whether segment 3 possessed or lacked ventral cirri. They then later scored ventral cirri as absent for the first 2 segments (no separate score for tentacular cirri) and present for the third in the character matrix However, in the

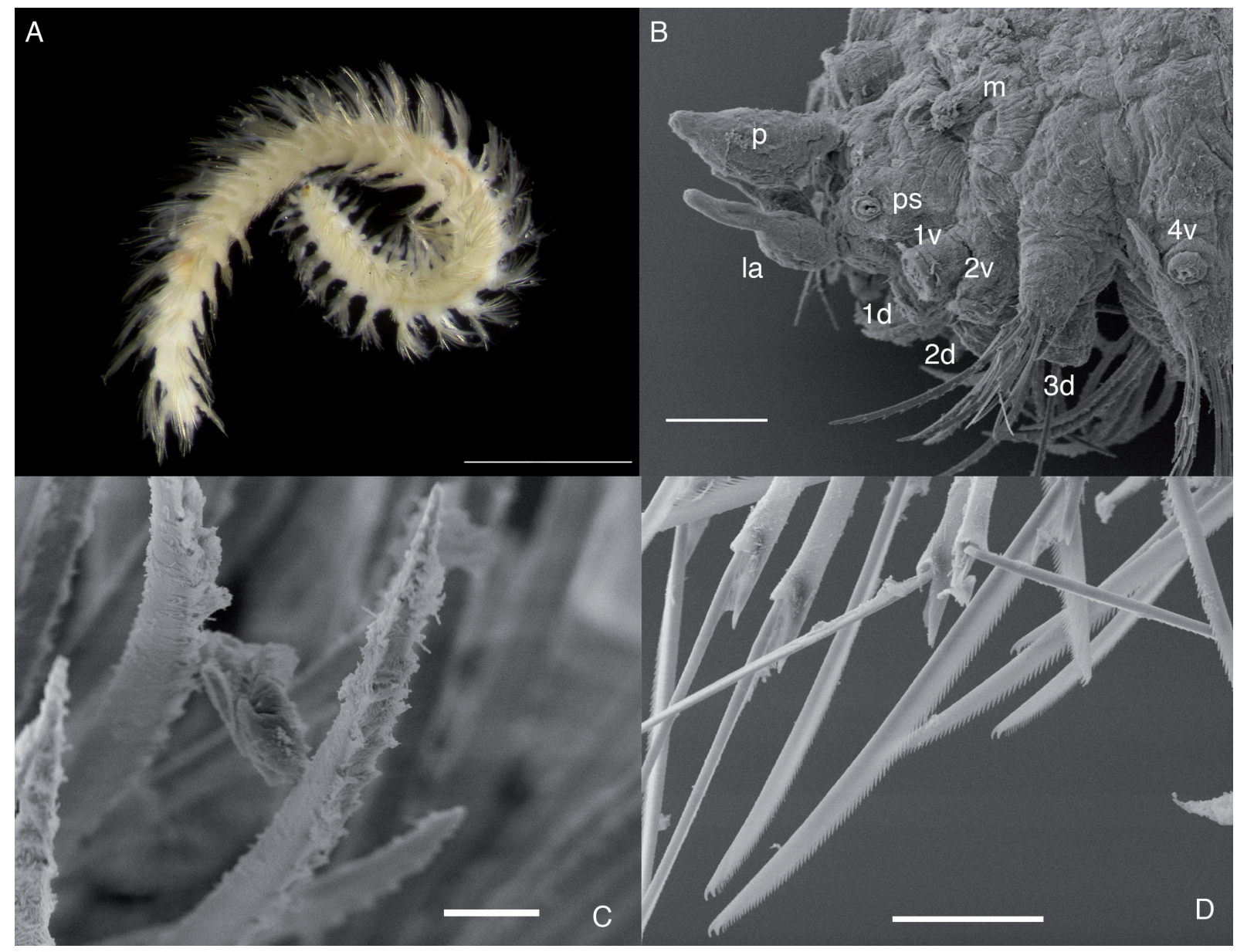

Fig. 2. Dysponetus joeli Olivier et al., 2012. A. NMW.Z.2009.027.0003, whole specimen, dorsal view (scale bar $1 \mathrm{~mm}$ ). B. NMW.Z.2009.027.0005, anterior end, ventrolateral view (scale bar $50 \mu \mathrm{m}$ ). C. Notochaetae (scale bar $10 \mu \mathrm{m})$. D. Neurochaetae (scale bar $20 \mu \mathrm{m}) .-\mathrm{d}=$ dorsal (cirrophore), $\mathrm{la}=$ lateral antenna, $\mathrm{m}=$ mouth appendage, $\mathrm{p}=$ palp, $\mathrm{ps}=$ palp scar, $\mathrm{v}=$ ventral (cirrophore); numbers indicate the segment. 
species key itself, $D$. joeli is keyed out with ventral cirri being present on the $3^{\text {rd }}$ segment (i.e. chaetiger 2). It is apparent from the character states scored for the other species in the matrix that the authors have used the term 'ventral cirrus' interchangeably with 'tentacular cirrus'. Earlier authorities have also been variable in their use of the terms 'tentacular cirrus' versus 'cirrus' with regards to the appendages of the first 3 segments in species of Dysponetus. In this paper, only the cirri of the first 2 segments, which lack parapodia and have cirrophores directly attached to the body wall, are regarded as being tentacular. A later paper will discuss the different characters of Dysponetus species in more detail.

The lack of ventral cirri on segment 3 distinguishes $D$. joeli from most other Dysponetus species. The only other species with this characteristic are D. bidentatus Day, 1954, D. bipapillatus and D. macroculatus, although $D$. bidentatus lacks ventral cirri on segment 2 also (Day 1954). The presence or absence of ventral cirri on segment 3 is unknown for $D$. hebes (Webster \& Benedict, 1887); however, this species differs considerably by having a double mouth appendage as opposed to single, and sphaerical not elongated palps. With the revised character for segment 3 , the species key in Olivier et al. would place $D$. joeli with both D. bipapillatus and D. macroculatus. The latter two species are distinguished in the key according to the relative size of the eyes; however, this is not a good character as the eye pigments degrade in alcohol and disappear over time - as is already evident in the type specimens. A new revised key to the 12 species of the genus is provided below.

Dysponetus joeli is a much larger species than both D. bipapillatus and D. macroculatus. Even the type specimens, described as 'small' (ranging from 3.5-4 mm in length, incomplete) and smaller than those from the Isles of Scilly, were 2-3 times the size of each of the latter species, respectively.

Dysponetus joeli is most similar to D. bipapillatus from the Mediterranean, sharing all of the obvious characteristics. The paired papillae on segment 8 described for D. bipapillatus were not observed on any of the $D$. joeli specimens; however, these appendages were only seen on a few specimens of D. bipapillatus and are thus not a good character for comparison. In his paper, Dahlgren (1996) stated that the specimens, though small, were considered mature adults due to the presence of the paired papillae, interpreted as genital organs, and the development of the anterior segments. A comparison of the individual characters shows $D$. joeli to possess twice as many neurochaetae as $D$. bipapillatus across all segments (20-26 compared to 9-13), more numerous denticles on the notochaetae (15-20 as opposed to $10-15)$ and a shorter pygidial projection $(40 \mu \mathrm{m}$ versus $50 \mu \mathrm{m})$, the last character particularly noticeable in relation to the larger body size of $D$. joeli. Similarly, the number of neurochaetae in $D$. joeli is greater than the 19-22 found on D. macroculatus, and, in general, the former species is a much larger animal than the latter, being 2-3 times as long at maturity (as evidenced by the presence of eggs in specimens of both).

\section{Key to Dysponetus species}

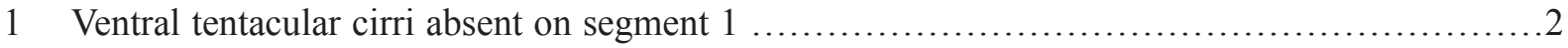

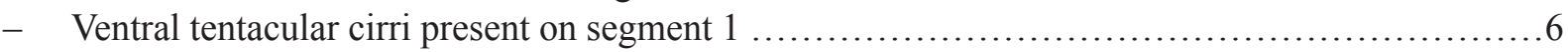

2 Elongate palps; 4 eyes ................................... bulbosus* Hartmann-Schröder, 1982

- Sphaerical palps; 2 eyes or eyes absent .................................................

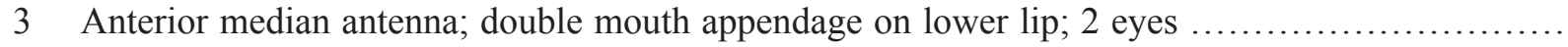
D. hebes (Webster \& Benedict, 1887)

- Dorsal median antenna; eyes absent ..................................................

4 Ventral tentacular cirri present on segment 2 ....................... g. gracilis Hartman, 1965

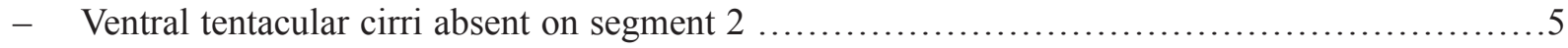


5 Mouth appendage absent; paleae present among notochaetae

.................................................. paleophorus Hartmann-Schröder, 1974

- Double mouth appendage on lower lip; paleae absent .............. . pygmaeus Levinsen, 1879

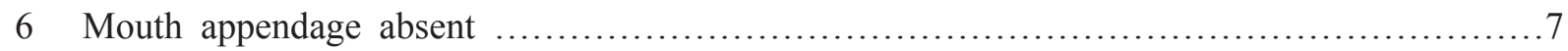

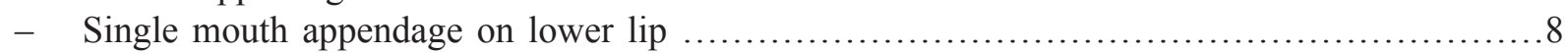

7 Elongate palps, ventral tentacular cirri present on segment 2 .....D. hesionides Böggemann, 2009

- Sphaerical palps, ventral tentacular cirri absent on segment 2 .....D. profundus Böggemann, 2009

8 Eyes absent, ventral cirri present on segment 3 .................... caecus (Langerhans, 1880)

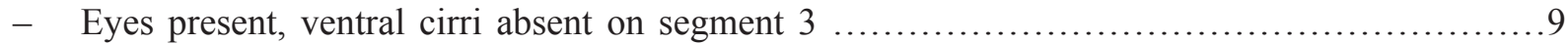

916 or less notochaetae in mid-body segments ...........D. bulbosus* Hartmann-Schröder, 1982

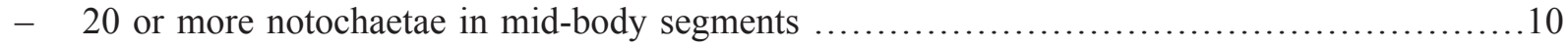

10 Ventral tentacular cirri absent on segment 2 .......................... bidentatus Day, 1954

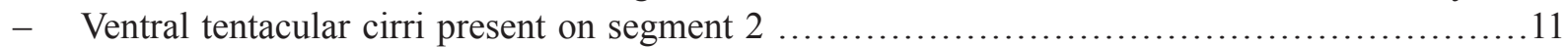

11 Few neurochaetae, only 9-13 in mid-body segments .............D. bipapillatus Dahlgren, 1996

- Numerous neurochaetae in mid-body segments, 19 or more ..............................12

12 Small body size, 2-3 mm; 19-22 neurochaetae .................. macroculatus Dahlgren, 1996

- Large body size, $>3 \mathrm{~mm} ; 20-26$ neurochaetae .................... joeli Olivier et al., 2012

* Descriptions of D. bulbosus (Hartmann-Schröder 1982, 1986) contradict each other over the presence or absence of ventral cirri on each of the first few segments. For this reason, D. bulbosus is included twice in the key to account for the discrepancy in descriptions. Dysponetus bulbosus will be reviewed in a forthcoming paper.

\section{Acknowledgements}

The work in the Isles of Scilly was part of the Assessment of Marine Biodiversity Linked to Ecosystems project funded by the Department for Environment, Food \& Rural Affairs (DEFRA). Thanks must go to Dr Richard Warwick and Dr Paul Somerfield who jointly led the project, the Captain and crew of the Marine Biological Association's Research Vessel Sepia and everyone else involved with the sampling. Elin Sigvaldodottír and Tarik Meziane are also thanked for the loan of specimens from the Swedish Museum of Natural History, Stockholm and Muséum National d'Histoire Naturelle in Paris that enabled this paper to be written. Dr Andrew Mackie is thanked for his comments and improvements on the paper.

\section{References}

Aguirrezabalaga F., San Martín G., Petersen M.E. \& Ceberio A. 1999. Presencia de Dysponetus gracilis Hartman, 1965 (Polychaeta, Chrysopetalidae) en las costas europeas, Golfo de Vizcaya. Boletín de la Real Sociedad Española de Historia Natural (Sección Biológica) 95: 23-27.

Annenkova N.P. 1935. Über Dysponetus pygmaeus Levinsen und Euzonus arcticus Grube. Comptes Rendus (Doklady) de l'Académie des Sciences de l'USSR 1935 3(5): 233-236.

Böggemann M. 2009. Polychaetes (Annelida) of the abyssal SE Atlantic. Organisms Diversity \& Evolution 9: 252-428. http://www.sciencedirect.com/science/journal/14396092

Brito M.C., Núñez J., Bacallado J.J. \& Ocaña, O. 1996. Anélidos poliquetos de Canarias: Orden Phyllodocida (Chrysopetalidae, Pisionidae, Glyceridae, Sphaerodoridae, Hesionidae y Pilargidae). In: 
Llinas O., González J.A. \& Rueda M.J. (eds), Oceanografia y recursos marinos en el Atlántico CentroOriental. Gobierno de Canarias, Gran Canaria, 158-179.

Dahlgren T.G. 1996. Two new species of Dysponetus (Polychaeta: Chrysopetalidae) from Italy and Papua New Guinea. Proceedings of the Biological Society of Washington 109: 575-585. http://www. biodiversitylibrary.org/item/107744\#page/599/mode/1up

Dahlgren T.G. \& Pleijel F. 1995. On the generic allocation of Chrysopetalum caecum (Polychaeta: Chrysopetalidae). Mitteilungen aus dem hamburgischen zoologischen Museum und Institut 92: 159-173.

Day J.H. 1954. The Polychaeta of Tristan da Cunha. Results of the Norwegian Scientific Expedition to Tristan da Cunha, 1937-1938, 29: 1-35.

Ehlers E. 1864. Die Borstenwürmer (Annelida Chaetopoda) nach systematischen und anatomischen Untersuchungen dargestellt. Leipzig, Wilhelm Engelmann, xx + pp. 1-268, pls 1-11. http://dx.doi. org/10.5962/bhl.title.2081

Hartman O. 1965. Deep-water benthic polychaetous annelids off New England to Bermuda and other North Atlantic areas. Occasional Papers of the Allan Hancock Foundation 28: 1-378.

Hartman O. \& Fauchald K. 1971. Deep-water benthic polychaetous annelids off New England to Bermuda and other North Atlantic areas. Part II. Allan Hancock Monographs in Marine Biology 6: $1-327$.

Hartmann-Schröder G. 1974. Polychaeten von Expeditionen der "Anton Dohrn" in Nordsee und Skagerrak. Veröffentlichungen des Instituts für Meeresforschung in Bremerhaven 14: 169-274.

Hartmann-Schröder G. 1982. Zur Kenntis des Eulitorals der australischen Küsten unter besonderer Berücksichtigung der Polychaeten und Ostracoden. Teil 8. Die Polychaeten der subtropisch-antiborealen Westküste Australiens (zwischen Cervantes im Norden und Cape Naturaliste im Süden). Mitteilungen aus dem hamburgischen zoologischen Museum und Institut 79: 51-118.

Hartmann-Schröder G. 1986. Zur Kenntis des Eulitorals der australischen Küsten unter besonderer Berücksichtigung der Polychaeten und Ostracoden. Teil 12. Die Polychaeten der antiborealen Südküste Australiens (zwischen Wallaroo im Westen und Port MacDonnell im Osten). Mitteilungen aus dem hamburgischen zoologischen Museum und Institut 83: 31-70.

Imajima M. \& Hartman O. 1964. The Polychaetous Annelids of Japan. Part 1. Allan Hancock Foundation Occasional Paper 26: 1-166.

Kirkegaard J.B. 1992. Havbørsteorme, I. Errantia. Danmarks Fauna 83: 1-416, figs 1-199.

Langerhans P. 1880. Die Würmfauna von Madeira. Zeitschrift für Wissenschaftliche Zoologie 33: 267316 , pls $14-17$.

Laubier L. 1964. Contribution à la faunistique du coralligène, VI. Presence de Chrysopetalum caecum Langerhans dans l'endofauna coralligène. Vie et Milieu 15: 125-138.

Levinsen G.M.R. 1879. Om to nye Slaegter af arctiske chaetopode Annelider. Videnskabelige Meddelelser fra Dansk Naturhistorisk Forening Kjøbenhavn, vol. for 1879-80: 9-18, pl. 1. http://www. biodiversitylibrary.org/item/110689\#page/1/mode/1up

O'Connor B.D.S. 1981. Polychaeta (Annelida) from Galway Bay, west coast of Ireland, new to the Irish fauna. Irish Natural History Journal 20: 355-361.

Olivier F., Lana P., Oliveira V. \& Worsfold T. 2012. Dysponetus joeli sp. nov. (Polychaeta: Chrysopetalidae) from the north-east Atlantic, with a cladistic analysis of the genus and a key to species. Journal of the Marine Biological Association of the UK 92: 989-996. http://dx.doi.org/10.1017/ $\underline{\mathrm{S} 0025315412000562}$ 
Parapar J. \& San Martín G. 1993. Anélidos poliquetos mesopsámmicos sublitorales de la costa de Ceuta (España). Cahiers de Biologie Marine 34: 363-381.

Webster H.E. \& Benedict J.E. 1887. The Annelida Chaetopoda, from Eastport, Maine. Annual Report of the United States Commission of Fish and Fisheries, Washington, vol. for 1885: 707-758, pls 1-8. http://docs.lib.noaa.gov/rescue/cof/COF 1885.PDF

Manuscript received: 17 August 2012

Manuscript accepted: 19 October 2012

Published on: 8 November 2012

Topic editor: Rudy Jocqué

In compliance with the $I C Z N$, printed versions of all papers are deposited in the libraries of the institutes that are members of the EJT Consortium: Muséum National d'Histoire Naturelle, Paris, France; National Botanic Garden of Belgium, Meise, Belgium; Royal Museum for Central Africa, Tervuren, Belgium; Natural History Museum, London, United Kingdom; Royal Belgian Institute of Natural Sciences, Brussels, Belgium; Natural History Museum of Denmark, Copenhagen, Denmark. 